\title{
Effect of dietary calcium intake and meal calcium content on calcium absorption in the rat
}

\author{
BY KEVIN D. CASHMAN AND ALBERT FLYNN* \\ Department of Nutrition, University College Cork, Republic of Ireland
}

(Received 28 July 1995 - Revised 19 December 1995 - Accepted 16 January 1996)

\begin{abstract}
Fifty-four male and forty-five female 7-week-old rats, Wistar strain, average weights $190 \mathrm{~g}$ and $140 \mathrm{~g}$ respectively, were randomized by weight into three groups of eighteen rats each (males) and three groups of fifteen rats each (females) and fed on a semi-purified diet containing (per $\mathrm{kg}$ ) 2 (low), 5 (normal) or $20 \mathrm{~g}$ (high) $\mathrm{Ca}$ as $\mathrm{CaCO}_{3}$ for 2 weeks. Each group was then further randomized into three groups of six rats each (males) and five rats each (females) and given a meal (10 $\mathrm{g}$ of the same diet) containing either 2,5 or $20 \mathrm{~g} \mathrm{Ca}$ as ${ }^{47} \mathrm{CaCO}_{3} \cdot{ }^{47} \mathrm{Ca}$ was determined in quantitative daily collections of faeces over $7 \mathrm{~d}$ and fractional absorption of ${ }^{47}$ Ca estimated by extrapolating the linear portion (days 3-7) of the plot of log ${ }^{47} \mathrm{Ca}$ retention $v$. time back to the time of isotope administration. Absorption of meal Ca was higher in males than in females and was affected similarly in males and females by previous dietary $\mathrm{Ca}$ intake and meal $\mathrm{Ca}$ content. Fractional absorption of meal $\mathrm{Ca}$ decreased with increasing previous dietary $\mathrm{Ca}$ intake and with increasing meal $\mathrm{Ca}$ content, and the combined effect of these two variables caused fractional Ca absorption to vary from 11-89\%. Absolute absorption of meal Ca decreased with increasing previous dietary $\mathrm{Ca}$ intake and increased with increasing meal $\mathrm{Ca}$ content. The influence on $\mathrm{Ca}$ absorption of variations in meal $\mathrm{Ca}$ content (load effect) was greater than that of variations in previous dietary $\mathrm{Ca}$ intake (adaptive effect). These results show that previous dietary $\mathrm{Ca}$ intake and meal $\mathrm{Ca}$ content are both major determinants of $\mathrm{Ca}$ absorption from meals in intact rats fed in the normal way and that the rat responds to these factors in a manner similar to that reported for humans. This study provides further evidence of similarities between rats and humans in dietary $\mathrm{Ca}$ absorption.
\end{abstract}

Calcium absorption: Calcium intake

The influence of dietary and physiological factors on the absorption of dietary $\mathrm{Ca}$ is poorly understood (Miller, 1989). While advances in methodology for the study of Ca absorption in humans using radioisotopes (Heaney et al. 1988) or stable isotopes (Fairweather-Tait et al. 1989) are improving our understanding of $\mathrm{Ca}$ bioavailability in foods, the wider application of these methods is limited by factors such as safety (radioisotopes) and cost (stable isotopes). Thus, there continues to be a need for suitable animal models to complement studies in humans, particularly when more detailed or mechanistic investigations are required, or to assist in the design of human studies.

The rat is the most widely used animal model for studies on $\mathrm{Ca}$ absorption and there is evidence that $\mathrm{Ca}$ absorption is affected similarly in rats and humans by a number of physiological and dietary factors. For example, $\mathrm{Ca}$ absorption in humans is increased by pregnancy (Cross et al. 1995), lactation (Heaney \& Skillman, 1971) and 1,25-dihydroxy cholecalciferol (Hall et al. 1969; Kaplan et al. 1977) and is also increased by these factors in rats (Dostal \& Toverud, 1984; Brommage, 1989; Brommage et al. 1990). Ageing reduces Ca absorption in humans (Heaney et al. 1989) and in rats (Buchowski \& Miller, 1991). Dietary factors which have been reported to reduce $\mathrm{Ca}$ absorption in humans include oxalic

* For reprints. 
acid (Heaney et al. 1988, 1990) and phytate (Heaney et al. 1991) and these have also been shown to reduce Ca absorption in rats (Weaver et al. 1987; Lönnerdal et al. 1989; Cashman \& Flynn, 1993). However, there is evidence that $\mathrm{Ca}$ absorption is affected differently in rats and humans by some dietary factors. For example, lactose has been reported to increase Ca absorption in rats (Miller et al. 1988; Buchowski \& Miller, 1991) and in human infants (Ziegler \& Fomon, 1983) but not in human adults (Tremaine et al. 1986), while dietary phosphate has been reported to inhibit Ca absorption in rats (Mahoney \& Hendricks, 1978) but either to have no effect on (Hegsted et al. 1981) or to enhance slightly (Zemel \& Linkswiler, 1981) Ca absorption in humans. This indicates that the rat may not be a uniformly good model for studies on factors affecting $\mathrm{Ca}$ absorption and there is a need to define better the conditions under which the rat is suitable as a model. Previous dietary $\mathrm{Ca}$ intake and meal $\mathrm{Ca}$ content ( $\mathrm{Ca}$ load) are important determinants of $\mathrm{Ca}$ absorption in humans. Although the influence of these factors on $\mathrm{Ca}$ absorption in rats has been clearly demonstrated for Ca solutions using the in situ ligated intestinal loop method (Pansu et al. 1981), the relative influence of these factors on $\mathrm{Ca}$ absorption from food, particularly under normal conditions of eating, is poorly defined.

In the present study the influence of previous dietary $\mathrm{Ca}$ intake and meal $\mathrm{Ca}$ content on $\mathrm{Ca}$ absorption from a meal was determined in rats under normal conditions of eating.

\section{MATERIALS AND METHODS}

Preparation of rat diets

The AIN-76 purified diet (American Institute of Nutrition, 1977) was used in the present study. The mineral mix was modified by replacing $\mathrm{CaHPO}_{4}$ with $\mathrm{CaCO}_{3}$ as the sole source of $\mathrm{Ca}$ and by including $\mathrm{KH}_{2} \mathrm{PO}_{4}$ and $\mathrm{K}_{2} \mathrm{HPO}_{4}$ to supply the $\mathrm{P}$ requirement (Table 1).

\section{Preparation of ${ }^{47} \mathrm{Ca}$-labelled meals}

Labelled $\mathrm{CaCO}_{3}$ was prepared by mixing ${ }^{47} \mathrm{Ca}$ (as ${ }^{47} \mathrm{CaCl}_{2}$ in $\mathrm{NaCl}(9 \mathrm{~g} / \mathrm{l})$, specific activity $7.9 \mathrm{GBq} / \mathrm{g}$; Forskningscenter Riso, 4000 Roskilde, Denmark) with $2 \mathrm{M}-\mathrm{CaCl}_{2}$, addition of a slight molar excess of $\mathrm{Na}_{2} \mathrm{CO}_{3}$ to precipitate $\mathrm{CaCO}_{3}$, and washing the precipitate on a filter, followed by drying at $100^{\circ}$. ${ }^{47} \mathrm{Ca}$-labelled meals containing 2,5 or $20 \mathrm{~g} \mathrm{Ca} / \mathrm{kg}$ were prepared by substituting ${ }^{47} \mathrm{Ca}-$ labelled $\mathrm{CaCO}_{3}$ for $\mathrm{CaCO}_{3}$ in the $\mathrm{AIN}-76$ diets outlined in Table 1.

\section{Calcium absorption study}

Rats ( 7 weeks old; fifty-four male, forty-five female), Wistar strain, average weights $190 \mathrm{~g}$ and $140 \mathrm{~g}$ for males and females respectively, were randomized by weight into three groups of eighteen rats each (males) and three groups of fifteen rats each (females) and fed $a d$ libitum on a purified diet (AIN-76) containing (per kg) 2.0 (low), 5.0 (normal) or $20.0 \mathrm{~g}$ (high) $\mathrm{Ca}$ as $\mathrm{CaCO}_{3}$ and $4.0 \mathrm{~g} \mathrm{P}$ and given distilled water ad libitum for $14 \mathrm{~d}$. Feed was provided at $\mathbf{1 7 . 0 0}$ hours each day. On the fifteenth day each group was then further randomized into three groups of six rats each (males; average weight $265 \mathrm{~g}$ ) or five rats each (females; average weight $180 \mathrm{~g}$ ). Rats were placed in individual cages with a grid-floor and a facility for separate collection of faeces and urine. After fasting for $10 \mathrm{~h}(09.00-19.00$ hours), animals were given overnight (19.00-09.00) a meal (10 g), containing (per $\mathrm{kg}$ ) either $2 \cdot 0,5 \cdot 0$ or $20 \cdot 0 \mathrm{~g} \mathrm{Ca}$ as ${ }^{47} \mathrm{Ca}$-labelled $\mathrm{CaCO}_{3}\left(0 \cdot 037 \mathrm{MBq}{ }^{47} \mathrm{Ca} / 10 \mathrm{~g}\right.$ meal $)$. On the following morning the radiolabelled meal was removed and any remaining feed was weighed, and after $4 \mathrm{~h}$, the rats were replaced on the diets to which they had been adapted.

$\mathrm{Ca}$ absorption was determined by a single-tracer faecal ${ }^{47} \mathrm{Ca}$ recovery method. Quantitative collections of faeces were made daily for $7 \mathrm{~d}$ after administration of the 
Table 1. Composition of the modified AIN-76 diet (American Institute of Nutrition, 1977)

\begin{tabular}{lc}
\hline \hline Ingredient* & Content $(\mathrm{g} / \mathrm{kg})$ \\
\hline Casein & $200 \cdot 0$ \\
DL-Methionine & $3 \cdot 0$ \\
Maize starch & $150 \cdot 0$ \\
Sucrose & $495 \cdot 0,(487 \cdot 5),(450 \cdot 0) \dagger$ \\
Fibre & $50 \cdot 0$ \\
Maize oil & $50 \cdot 0$ \\
AIN mineral mix & $35 \cdot 0$ \\
AIN vitamin mix§ & $10 \cdot 0$ \\
Calcium carbonate & $5 \cdot 0,(12 \cdot 5),(50 \cdot 0) \dagger$ \\
Choline bitartrate & $2 \cdot 0$ \\
\hline
\end{tabular}

* Sources of ingredients: casein (sodium caseinate, Kerrymore Milk Products Ltd, Listowel, Co. Kerry, Ireland); DL-methionine (Rhone Poulenc, Animal Nutrition, Commentry, France); maize starch (Cagill, Bergen op Zoom, the Nederlands); sucrose (Irish Sugar plc, Sugar Division, Athy Road, Carlow, Ireland); fibre (Avicel microcrystalline cellulose, N.F., FMC International, Food and Pharmaceutical Products Division, Little Island, Cork, Ireland); maize oil (St. Bernard's brand, Dunnes Stores Ltd, 67 Stephen Street, Upper Dublin 8, Ireland); choline bitartrate (Brown and Gilmore, Carrigaline East, Co. Cork, Ireland).

$\dagger$ Representing diets containing (per kg) $2 \cdot 0$ (low), 5.0 (normal) or $20 \cdot 0 \mathrm{~g}$ (high) $\mathrm{Ca}$.

+ Contained $(\mathrm{g} / \mathrm{kg})$ : potassium dihydrogen phosphate 376 , dipotassium hydrogen phosphate 160 , sodium chloride 74 , magnesium oxide, 24 , manganous carbonate $3 \cdot 5$, ferric citrate 6 , zinc carbonate $1 \cdot 6$, cupric carbonate $0 \cdot 3$, potassium iodate 0.01 , sodium selenite 0.01 , chromium potassium sulphate 0.55 , sucrose 354 .

$\S$ Contained $(/ \mathrm{kg})$ : nicotinic acid $3 \mathrm{~g}$, calcium pantothenate $1.6 \mathrm{~g}$, riboflavin $600 \mathrm{mg}$, thiamin- $\mathrm{HCl} 600 \mathrm{mg}$, pyridoxine-HCl $700 \mathrm{mg}$, pteroylmonoglutamic acid $200 \mathrm{mg}$, biotin $20 \mathrm{mg}$, cyanocobalamin $1 \mathrm{mg}$, cholecalciferol $2.5 \mathrm{mg}$, menaquinone $5.0 \mathrm{mg}$, retinyl palmitate $120 \mathrm{mg}$, DL- $\alpha$ tocopheryl acetate $5000 \mathrm{mg}$.

labelled meal. ${ }^{47} \mathrm{Ca}$ in the meal samples and in daily faecal collections was determined in a well $\gamma$ counter (Compugamma, LKB Wallac, LKB Instruments Ltd, South Croydon, Surrey) using an energy range of $1144-1295 \mathrm{keV}$. Net $\mathrm{Ca}$ absorption was calculated as the difference between ingested and faecal ${ }^{47} \mathrm{Ca}$. Fractional absorption of ${ }^{47} \mathrm{Ca}$ was estimated by extrapolating the linear portion (days $3-7$ ) of the plot of $\log$ net ${ }^{47} \mathrm{Ca}$ absorption $v$. time back to the time of isotope administration.

In order to obtain an estimate of urinary losses of ${ }^{47} \mathrm{Ca}$, urine collections were made for selected groups of animals for each of the first $3 \mathrm{~d}$ after feeding the labelled meal. Cumulative urinary loss over the first $3 \mathrm{~d}$ was expressed as a percentage of administered dose and also as a percentage of absorbed dose.

\section{Statistical methods}

${ }^{47} \mathrm{Ca}$ absorption data were subjected to both three-way ANOVA, with variation attributed to sex, dietary $\mathrm{Ca}$ and meal $\mathrm{Ca}$ and two-way $\mathrm{ANOVA}$, with variation attributed to dietary $\mathrm{Ca}$ and meal Ca. Urinary ${ }^{47} \mathrm{Ca}$ data were subjected to one-way ANOVA. To follow up the ANOVA, all pairs of means were compared by the method of least significant difference (Snedecor \& Cochran, 1967).

\section{RESULTS}

The effects of the three factors, i.e. dietary $\mathrm{Ca}$, meal $\mathrm{Ca}$ and sex of the rat, on fractional $\mathrm{Ca}$ absorption in 9-week-old rats were evaluated by three-way ANOVA. This showed that there was no three-way interaction between dietary $\mathrm{Ca}$, meal $\mathrm{Ca}$ and sex. Neither were there any two-way interactions between these factors. However, each factor had a significant effect on fractional $\mathrm{Ca}$ absorption. Fractional $\mathrm{Ca}$ absorption in males was significantly higher than that in females. Because of this, the effects of dietary $\mathrm{Ca}$ intake and meal $\mathrm{Ca}$ 
Table 2. Effect of dietary calcium intake and meal calcium content on calcium absorption in 9-week-old rats*

(Mean values with the pooled standard error of the mean)

\begin{tabular}{|c|c|c|c|c|c|c|c|}
\hline \multirow[b]{3}{*}{ Dietary $\mathrm{Ca}(\mathrm{g} / \mathrm{kg})$} & \multirow[b]{3}{*}{ Meal Ca $(\mathrm{g} / \mathrm{kg})$} & \multicolumn{6}{|c|}{$\mathrm{Ca}$ absorption } \\
\hline & & \multicolumn{3}{|c|}{ Male } & \multicolumn{3}{|c|}{ Female } \\
\hline & & $n$ & $(\%)$ & $(\mathrm{mg})$ & $n$ & $(\%)$ & $(\mathrm{mg})$ \\
\hline \multirow[t]{3}{*}{$2 \cdot 0$} & $2 \cdot 0$ & 6 & $89 \cdot 0$ & $17 \cdot 8$ & 5 & $83 \cdot 7$ & 16.7 \\
\hline & $5 \cdot 0$ & 6 & $76 \cdot 0$ & $38 \cdot 0$ & 5 & $53 \cdot 7$ & $26 \cdot 9$ \\
\hline & $20 \cdot 0$ & 6 & $39 \cdot 7$ & $79 \cdot 5$ & 5 & $37 \cdot 1$ & $74 \cdot 2$ \\
\hline \multirow[t]{3}{*}{$5 \cdot 0$} & $2 \cdot 0$ & 6 & $69 \cdot 8$ & $14 \cdot 0$ & 5 & 73.7 & $14 \cdot 7$ \\
\hline & $5 \cdot 0$ & 6 & $48 \cdot 5$ & $24 \cdot 2$ & 5 & $41 \cdot 4$ & $20 \cdot 7$ \\
\hline & $20 \cdot 0$ & 6 & $24 \cdot 8$ & $49 \cdot 7$ & 5 & $17 \cdot 9$ & $35 \cdot 8$ \\
\hline \multirow[t]{3}{*}{$20 \cdot 0$} & 2.0 & 6 & $65 \cdot 9$ & $13 \cdot 2$ & 5 & $55 \cdot 2$ & $11 \cdot 0$ \\
\hline & $5 \cdot 0$ & 6 & $43 \cdot 6$ & $21 \cdot 8$ & 5 & $35 \cdot 6$ & $17 \cdot 8$ \\
\hline & $20 \cdot 0$ & 6 & $18 \cdot 4$ & $36 \cdot 9$ & 5 & $17 \cdot 5$ & $35 \cdot 0$ \\
\hline Pooled SEM & & & $4 \cdot 3$ & $3 \cdot 8$ & & 3.8 & $5 \cdot 2$ \\
\hline \multicolumn{8}{|c|}{$\begin{array}{l}\text { Significant }(P) \text { of variance } \\
\text { ratio, effect of: }\end{array}$} \\
\hline Dietary Ca & & & $<0.001$ & $<0.001$ & & $<0.001$ & $<0.001$ \\
\hline Meal Ca & & & $<0.001$ & $<0.001$ & & $<0.001$ & $<0.001$ \\
\hline Dietary $\mathrm{Ca} \times$ meal & & & NS & $<0.001$ & & NS & $<0.010$ \\
\hline \multicolumn{3}{|c|}{ Least significant difference $(P<0.05)$ : } & $12 \cdot 2$ & $11 \cdot 0$ & & $10 \cdot 8$ & $15 \cdot 0$ \\
\hline
\end{tabular}

* For details of diets and procedures, see Table 1 and pp. 464465.

content on $\mathrm{Ca}$ absorption were assessed separately for males and females using two-way ANOVA.

Two-way ANOVA showed that fractional absorption of meal $\mathrm{Ca}$ was significantly affected by previous dietary $\mathrm{Ca}$ intake and meal $\mathrm{Ca}$ content in both male and female rats (Table 2). Fractional absorption of meal $\mathrm{Ca}$ decreased with increasing previous dietary $\mathrm{Ca}$ intake and with increasing meal $\mathrm{Ca}$ content in both males and females. Fractional $\mathrm{Ca}$ absorption in males varied from $89 \%$ on the low-Ca diet-low-Ca meal to $18 \%$ on the highCa diet-high-Ca meal (Table 2) while fractional $\mathrm{Ca}$ absorption in females varied from $84 \%$ on the low-Ca diet-low-Ca meal to $18 \%$ on the high-Ca diet-high-Ca meal (Table 2).

Absolute absorption of meal $\mathrm{Ca}$ was significantly affected by previous dietary $\mathrm{Ca}$ intake and meal $\mathrm{Ca}$ content in both male and female rats (Table 2). Absolute absorption of meal $\mathrm{Ca}$ decreased with increasing previous dietary $\mathrm{Ca}$ intake but increased with increasing meal $\mathrm{Ca}$ content in both males and females. Absolute $\mathrm{Ca}$ absorption from a $10 \mathrm{~g}$ meal in males varied from $80 \mathrm{mg}$ on the low-Ca diet-high-Ca meal to $13 \mathrm{mg}$ on the high-Ca diet-low-Ca meal (Table 2). Absolute Ca absorption from a $10 \mathrm{~g}$ meal in females varied from $74 \mathrm{mg}$ on the low-Ca diet-high-Ca meal to $11 \mathrm{mg}$ on the high-Ca diet-high-Ca meal (Table 2).

The significant two-way interaction between dietary $\mathrm{Ca}$ and meal $\mathrm{Ca}$ for absolute $\mathrm{Ca}$ absorption (Table 2) shows that the effect of meal Ca content on absolute $\mathrm{Ca}$ absorption varies inversely with previous dietary $\mathrm{Ca}$ intake, and that the influence of previous dietary $\mathrm{Ca}$ intake on $\mathrm{Ca}$ absorption from a meal increases with increasing Ca content of the meal.

The effect of dietary $\mathrm{Ca}$ intake and meal $\mathrm{Ca}$ content on cumulative urinary ${ }^{47} \mathrm{Ca}$ loss in selected groups of male rats can be seen in Table 3 . Over the first $3 \mathrm{~d}$, only $2-4 \%$ of the administered ${ }^{47} \mathrm{Ca}$ dose appeared in the urine. Urinary ${ }^{47} \mathrm{Ca}$ excretion, expressed as percentage of the administered dose, was not significantly affected by previous dietary $\mathrm{Ca}$ 
Table 3. Effect of dietary calcium intake and meal calcium content on cumulative urinary loss of ${ }^{47} \mathrm{Ca}$ in male rats*

(Mean values with their standard errors)

\begin{tabular}{|c|c|c|c|c|c|c|c|c|c|c|}
\hline \multirow{4}{*}{$\begin{array}{c}\text { Dietary Ca } \\
(\mathrm{g} / \mathrm{kg})\end{array}$} & \multirow{4}{*}{$\begin{array}{c}\text { Meal Ca } \\
(\mathrm{g} / \mathrm{kg})\end{array}$} & & \multicolumn{8}{|c|}{ Cumulative urinary ${ }^{47} \mathrm{Ca}$ losses } \\
\hline & & & \multicolumn{6}{|c|}{ Administered dose (\%) } & \multirow{2}{*}{\multicolumn{2}{|c|}{$\begin{array}{c}\begin{array}{c}\text { Absorbed } \\
\text { dose }(\%)\end{array} \\
\text { Day } 3\end{array}$}} \\
\hline & & & \multicolumn{2}{|c|}{ Day 1} & \multicolumn{2}{|c|}{ Day 2} & \multicolumn{2}{|c|}{ Day 3} & & \\
\hline & & $n$ & Mean & SE & Mean & SE & Mean & SE & Mean & SE \\
\hline $2 \cdot 0$ & $2 \cdot 0$ & 6 & 0.6 & 0.4 & 1.8 & 0.4 & 2.5 & 0.4 & 2.8 & 0.4 \\
\hline \multirow[t]{3}{*}{5.0} & $2 \cdot 0$ & 6 & 0.7 & 0.4 & $2 \cdot 1$ & 0.3 & $2 \cdot 3$ & 0.3 & $3 \cdot 3$ & 0.4 \\
\hline & 5.0 & 6 & 0.7 & 0.2 & $2 \cdot 3$ & 0.5 & 3.9 & 0.6 & 8.0 & 1.2 \\
\hline & $20 \cdot 0$ & 6 & $1 \cdot 3$ & 0.7 & 3.8 & 0.5 & $4 \cdot 3$ & 0.4 & $17 \cdot 3$ & 1.6 \\
\hline $20 \cdot 0$ & $20 \cdot 0$ & 6 & $1 \cdot 3$ & 0.8 & $2 \cdot 3$ & 0.5 & $4 \cdot 3$ & 0.4 & $23 \cdot 4$ & $2 \cdot 2$ \\
\hline \multirow{2}{*}{\multicolumn{2}{|c|}{$\begin{array}{l}\text { ANOVA (one-way), } P \text { value } \\
\text { Least significant difference } \\
(P<0.05)\end{array}$}} & & \multirow{2}{*}{\multicolumn{2}{|c|}{$\begin{array}{l}\text { NS } \\
1.6\end{array}$}} & \multirow{2}{*}{\multicolumn{2}{|c|}{$\begin{array}{l}\text { NS } \\
1.6\end{array}$}} & \multirow{2}{*}{\multicolumn{2}{|c|}{$\begin{array}{l}\text { NS } \\
2.7\end{array}$}} & \multirow{2}{*}{\multicolumn{2}{|c|}{$\begin{array}{c}<0.001 \\
7 \cdot 3\end{array}$}} \\
\hline & & & & & & & & & & \\
\hline
\end{tabular}

* For details of diets and procedures, see Table 1 and pp. 464-465.

intake or meal $\mathrm{Ca}$ content. When urinary ${ }^{47} \mathrm{Ca}$ losses were expressed as a percentage of absorbed ${ }^{47} \mathrm{Ca}$ dose increasing meal $\mathrm{Ca}$ content significantly increased urinary ${ }^{47} \mathrm{Ca}$ loss while increasing previous dietary $\mathrm{Ca}$ content had no effect.

Endogenous loss of ${ }^{47} \mathrm{Ca}$ in faeces, as determined from the slope of the plot of $\log { }^{47} \mathrm{Ca}$ retention $v$. time, from day 3 to day 7 , was negligible, regardless of previous dietary $\mathrm{Ca}$ intake or meal Ca content.

\section{DISCUSSION}

In the present study fractional absorption of meal Ca was significantly higher in male rats than in females. This could be due to the higher growth rates of the male rats which would lead to a greater demand for $\mathrm{Ca}$ for skeletal mineralization, resulting in a greater efficiency of Ca absorption.

Separate statistical analysis of data for males and females using two-way ANOVA showed that both previous dietary $\mathrm{Ca}$ intake and meal $\mathrm{Ca}$ content affected fractional $\mathrm{Ca}$ absorption from a meal similarly in males and females. Fractional absorption of meal $\mathrm{Ca}$ decreased with increasing previous dietary $\mathrm{Ca}$ intake and with increasing meal $\mathrm{Ca}$ content. The combined effects of these two variables caused fractional absorption of meal Ca to vary in the range of $11-89 \%$, indicating that these variables are major determinants of $\mathrm{Ca}$ absorption.

Ca balance studies in rats (Henry \& Kon, 1953; Benson et al. 1969) fed on solid feeds have previously shown that fractional $\mathrm{Ca}$ absorption decreases with increasing dietary $\mathrm{Ca}$ intake. However, a limitation of these studies was that the effect of meal Ca content on $\mathrm{Ca}$ absorption could not be separated from the effect of previous dietary $\mathrm{Ca}$ intake since isotopic tracers were not used. The results of the present study are also in agreement with the findings of Weeks \& King (1985) who reported that fractional $\mathrm{Ca}$ absorption from cows' milk labelled with ${ }^{47} \mathrm{Ca}$ in rats adapted to a low-Ca diet $(2 \mathrm{~g} / \mathrm{kg})$ was higher than in rats adapted to a normal-Ca diet $(5 \mathrm{~g} / \mathrm{kg})$. However, these authors found no difference in fractional $\mathrm{Ca}$ absorption from $5 \mathrm{ml}$ milk compared with a meal of $10 \mathrm{ml}$ milk. 
The results of the present study show that both previous dietary $\mathrm{Ca}$ intake and meal $\mathrm{Ca}$ content have a major influence on Ca absorption in intact rats fed on solid feed in the normal way. This is similar to the findings obtained by Pansu et al. (1981) in studies on Ca absorption from $\mathrm{Ca}$ solutions in rats using in situ perfusion of intestinal loops.

The findings of the present study are also in agreement with human studies which found that fractional $\mathrm{Ca}$ absorption decreased with increasing previous dietary $\mathrm{Ca}$ intake (Ireland \& Fordtran, 1973; Heaney et al. 1975, 1989; Heaney, 1991) and with increasing meal Ca content (Ireland \& Fordtran, 1973; Heaney, 1991). The change in fractional Ca absorption with meal $\mathrm{Ca}$ content ( $\mathrm{Ca}$ load) is due to a 'physico-chemical' effect, resulting in the absorption of a larger fraction of a small load than of a large, while the change in $\mathrm{Ca}$ absorption with previous $\mathrm{Ca}$ intake represents a calcitriol-mediated adaptation of active transport (Heaney, 1991). Absolute Ca absorption from the meal in both male and female rats decreased with increasing previous dietary $\mathrm{Ca}$, while it increased with increasing meal $\mathrm{Ca}$ content. This has also been demonstrated in rats using in situ perfusion of intestinal loops with $\mathrm{Ca}$ solutions (Pansu et al. 1981) and is similar to the findings of Ireland \& Fordtran (1973) and Heaney (1991) in human studies.

The effects of the two processes of $\mathrm{Ca}$ absorption are illustrated in the present study when a 10 -fold change in dietary $\mathrm{Ca}$ intake occurs. When rats adapted to a low-Ca diet are changed on to a high-Ca diet, there is an immediate increase in $\mathrm{Ca}$ absorption as a result of the meal effect (reflecting increased absorption via both the passive paracellular and the active transcellular pathways), which is then modulated over time by a decrease in absorption due to the adaptive effect (reflecting a reduction in the capacity of the active transcellular pathway). When rats adapted to the high-Ca diet change to a low-Ca diet, there is an immediate reduction in $\mathrm{Ca}$ absorption as a result of the meal effect (probably mainly due to a decrease in Ca absorption via the passive paracellular pathway), which is then modulated over time by an increase in absorption due to the adaptive effect (reflecting increased capacity of the active transcellular pathway).

The results of this present study show that the influence of variations in meal Ca content on $\mathrm{Ca}$ absorption (load effect) was greater than that of variations in previous dietary $\mathrm{Ca}$ intake (adaptive effect), in agreement with findings in humans (Heaney, 1991). In the case of male rats, a 10-fold difference in meal Ca content $(2-20 \mathrm{~g} / \mathrm{kg})$ resulted in increments of $61.7,35.7$ and $23.7 \mathrm{mg}$ respectively in $\mathrm{Ca}$ absorption for animals habituated to low-, normal- and high-Ca diets, while a 10 -fold difference in dietary $\mathrm{Ca}$ content $(2-20 \mathrm{~g} / \mathrm{kg})$ resulted in increments of $42.6,16.2$ and $4.6 \mathrm{mg}$ respectively in $\mathrm{Ca}$ absorption for the high-, normal- and low-Ca meals. Similar observations were made for females.

Overall, urinary ${ }^{47} \mathrm{Ca}$ loss was small, with only $2-4 \%$ of the administered dose lost in urine in the first $3 \mathrm{~d}$ after isotope administration. These findings are similar to those of McCredie et al. (1984), who reported that only $1.7 \%$ of the ${ }^{47} \mathrm{Ca}$ administered to rats as an oral dose of $\mathrm{CaCl}_{2}$ appeared in the urine within $2 \mathrm{~d}$. When urinary ${ }^{47} \mathrm{Ca}$ loss was expressed as a percentage of the absorbed dose, it was found that increasing meal Ca increased the urinary ${ }^{47} \mathrm{Ca}$ losses significantly. This finding shows that at lower $\mathrm{Ca}$ loads ${ }^{47} \mathrm{Ca}$ retention approximates fractional absorption while at higher loads ${ }^{47} \mathrm{Ca}$ retention may be significantly lower than fractional absorption.

The results also suggest that $\mathrm{Ca}\left(\right.$ as $\left.\mathrm{CaCO}_{3}\right)$ is potentially totally available to rats from a purified diet, subject to $\mathrm{Ca}$ need and $\mathrm{Ca}$ content of the diet. This confirms the findings of human studies (Sheikh et al. 1987; Recker et al. 1988) in which $\mathrm{CaCO}_{3}$ was reported to be a good source of bioavailable $\mathrm{Ca}$, as good as milk and some milk products. The overall findings of the present study show that this rat model responds to two of the key determinants of $\mathrm{Ca}$ absorption in a manner similar to that reported for humans and provides further evidence of similarities between rats and humans in dietary Ca absorption. 
This work was part-funded by the Department of Agriculture, Food and Forestry, Dublin under the Food Industry Sub-Programme of EU Structural Funds, 1994-9.

\section{REFERENCES}

American Institute of Nutrition (1977). Report of the American Institute of Nutrition ad hoc committee on standards for nutritional studies. Journal of Nutrition 107, 1340-1348.

Benson, J. D., Emery, R. S. \& Thomas, J. W. (1969). Effects of previous calcium intakes on adaptation to low and high calcium diets in rats. Journal of Nutrition 97, 53-60.

Brommage, R. (1989). Measurement of calcium and phosphorus fluxes during lactation in the rat. Journal of Nutrition 119, 428-438.

Brommage, R., Baxter, D. C. \& Gierke, L. W. (1990). Vitamin D-independent intestinal calcium and phosphorus absorption during reproduction. American Journal of Physiology 259, G631-G638.

Buchowski, M. S. \& Miller, D. D. (1991). Lactose, calcium source and age affect calcium bioavailability in rats. Journal of Nutrition 121, 1746-1754.

Cashman, K. \& Flynn, A. (1993). Calcium absorption from cow's milk and soya milks in young rats. Proceedings of the Nutrition Society 52, 273A.

Cross, N. A., Hillman, L. S., Allen, S. H., Krause, G. F. \& Vieira, N. E. (1995). Calcium homeostasis and bone metabolism during pregnancy, lactation, and postweaning: a longitudinal study. American Journal of Clinical Nutrition 61, 514-523.

Dostal, L. A. \& Toverud, S. U. (1984). Effect of vitamin $\mathrm{D}_{3}$ on duodenal calcium absorption in vivo during early development. American Journal of Physiology 246, G528-G534.

Fairweather-Tait, S. J., Johnson, A., Eagles, J., Ganatra, S., Kennedy, H. \& Gurr, M. I. (1989). Studies on calcium absorption from milk using a double-label stable isotope technique. British Journal of Nutrition $\mathbf{6 2}$, 379-388.

Hall, B. D., MacMillan, D. R. \& Bronner, F. (1969). Vitamin D-resistant rickets associated with high fecal endogenous calcium output: a report of two cases. American Journal of Clinical Nutrition 22, 448-457.

Heaney, R. P. (1991). Human calcium absorptive performance. In Nutritional Aspects of Osteoporosis, pp. 115-123 [P. Burckhardt and R. P. Heaney, editors]. New York: Raven Press.

Heaney, R. P., Recker, R. R., Stegman, M. R. \& Moy, A. J. (1989). Calcium absorption in women: relationships to calcium intake, estrogen status, and age. Journal of Bone and Mineral Research 4, 469-475.

Heaney, R. P., Recker, R. R. \& Weaver, C. M. (1990). Absorbability of calcium sources: the limited role of solubility. Calcified Tissue International 46, 300-304.

Heaney, R. P., Saville, P. D. \& Recker, R. R. (1975). Calcium absorption as a function of calcium intake. Journal of Laboratory and Clinical Medicine 85, 881-890.

Heaney, R. P. \& Skillman, T. G. (1971). Calcium metabolism in normal human pregnancy. Journal of Clinical Endocrinology 33, 661-669.

Heaney, R. P., Weaver, C. M. \& Fitzsimmons, M. C. (1991). Soybean phytate content: effect on calcium absorption. American Journal of Clinical Nutrition 53, 745-747.

Heaney, R. P., Weaver, C. M. \& Recker, R. R. (1988). Calcium absorbability from spinach. American Journal of Clinical Nutrition 47, 707-709.

Hegsted, M., Schuette, S. A., Zemel, M. B. \& Linkswiler, H. M. (1981). Urinary calcium and calcium balance in young men as affected by level of protein and phosphorus intake. Journal of Nutrition 111, 553-562.

Henry, K. \& Kon, S. K. (1953). The relationship between calcium retention and body stores of calcium in the rat: effect of age and vitamin D. British Journal of Nutrition 7, 147-152.

Ireland, P. \& Fordtran, J. S. (1973). Effect of dietary calcium and age on jejunal calcium absorption in humans studied by intestinal perfusion. Journal of Clinical Investigation 52, 2672-2681.

Kaplan, R. A., Haussler, M. R., Deftos, L. J., Bone, H. \& Pak, C. Y. C. (1977). The role of 1,25 dihydroxyvitamin $\mathrm{D}$ in the mediation of intestinal hyperabsorption of calcium in primary hyperthyroidism and adsorptive hypercalciuria. Journal of Clinical Investigation 59, 756-760.

Lönnerdal, B., Sandberg, A. S., Sandstrom, B. \& Kunz, C. (1989). Inhibitory effects of phytic acid and other inositol phosphates on zinc and calcium absorption in suckling rats. Journal of Nutrition 119, 211-214.

McCredie, D. A., Troehler, U. \& Bonjour, J. P. (1984). In vivo determination of intestinal calcium absorption, with scandium-47 used as a marker. Journal of Laboratory and Clinical Medicine 103, 354-362.

Mahoney, A. W. \& Hendricks, D. G. (1978). Some effects of different compounds on iron and calcium absorption. Journal of Food Science 43, 1473-1476.

Miller, D. D. (1989). Calcium in the diet: food sources, recommended intakes, and nutritional bioavailability. Advances in Food and Nutrition Research 33, 103-156.

Miller, S. C., Miller, M. A. \& Omura, T. H. (1988). Dietary lactose improves endochondral growth and bone development and mineralization in rats fed a vitamin D-deficient diet. Journal of Nutrition 118, 72-77.

Pansu, D., Bellaton, C. \& Bronner, F. (1981). Effect of Ca intake on saturable and nonsaturable components of duodenal Ca transport. American Journal of Physiology 240, G32-G37. 
Recker, R. R., Bammi, A., Barger-Lux, M. J. \& Heaney, R. P. (1988). Calcium absorbability from milk products, an imitation milk, and calcium carbonate. American Journal of Clinical Nutrition 47, 93-95.

Sheikh, M. S., Santa Ana, C. A., Nicar, M. J., Schiller, L. R. \& Fordtran, J. S. (1987). Gastrointestinal absorption of calcium from milk and calcium salts. New England Journal of Medicine 317, 532-536.

Snedecor, G. W. \& Cochran, W. G. (1967). Statistical Methods. Ames, Iowa: Iowa State University Press.

Tremaine, W. J., Newcomer, A. D., Riggs, B. L. \& McGill, B. D. (1986). Calcium absorption from milk in lactasedeficient and lactase-sufficient adults. Digestive Diseases and Sciences 31, 376-378.

Weaver, C. M., Martin, B. R., Ebner, J. S. \& Krueger, C. A. (1987). Oxalic acid decreases calcium absorption in rats. Journal of Nutrition 117, 1903-1906.

Weeks, C. E. \& King, R. L. (1985). Bioavailability of calcium in heat-processed milk. Journal of Food Science 50, 1101-1105.

Zemel, M. B. \& Linkswiler, H. M. (1981). Calcium metabolism in the young adult male as affected by level and form of phosphorus intake and level of calcium intake. Journal of Nutrition 111, 315-324.

Ziegler, E. E. \& Fomon, S. J. (1983). Lactose enhances mineral absorption in infancy. Journal of Pediatric Gastroenterology and Nutrition 2, 288-294. 